\title{
Amniyotik membran ve sıvı kaynaklı tedaviler - kök hücre tedavisi
}

\section{Amniotic membrane and fluid derived treatments - stem cell therapy}

\author{
H. Atıl Atilla ${ }^{1,2}$, Allston J. Stubbs ${ }^{2}$ \\ 'Sağlık Bilimleri Üniversitesi Dışkapı Yıldırım Beyazıt Eğitim ve Araştırma Hastanesi, Ortopedi ve Travmatoloji Kliniği, Ankara \\ ${ }^{2}$ Wake Forest Üniversitesi Ortopedi Bölümü, Spor Cerrahisi ve Kalça Merkezi, ABD
}

Tüm alanlarda olduğu kadar kas iskelet sisteminde de, doku mühendisliği ve hücre tedavileri gibi rejeneratif tıp uygulamaları bilimsel araştırma sahasında kendine geniş yer bulmuş ve hızla gelişmektedir. Bu tedaviler için ideal kaynak ve donör arayışı devam etmektedir. Amniyotik membran, amniyotik sıvı ve bunlardan kaynaklanan kök hücreler ile tedavi ve doku mühendisliği, invaziv olmayan izolasyon, multipotensi, kolay kendini yenileyebilme, düşük immünojenite, anti-inflamatuvar etki, nontümörijenik özellik ve sınırlı etik sorun ile, rejeneratif tıp ve kas iskelet sistemi uygulamalarında yeni bir potansiyel olarak karşımıza çıkmaktadır.

Anahtar sözcükler: amniyotik kök hücre; rejeneratif tıp; kas-iskelet sistemi
In accordance with other medical branches, regenerative medicine applications as tissue engineering and cell therapies have found a wide range of scientific research opportunities and grows rapidly in the musculoskeletal field. The search for the ideal source and donor site of these treatments is still going on. Treatment and tissue engineering with amniotic membrane and amniotic fluid derived stem cells emerges as a new potential in regenerative medicine and the treatment of musculoskeletal system, with the advantages of non-invasive isolation, multipotency, rapid self regeneration, low immunogenecity, anti-inflammatory effect, non-tumorigenic feature, and limited ethical problems.

Key words: amniotic stem cell; regenerative medicine; musculoskeletal system on 20-25 yılda, gelişmiş laboratuvar olanakları sayesinde, insan kök hücrelerinin doku mühendisliği ve hastalıkların tedavisinde kullanımı hızla arttı. Tedavisi çok zor veya imkansız denilebilecek bazı hastalıklar için umut kaynağı olan bu gelişmelerde önemli yollar kat edilmekle beraber, bu tedavilerin vaat ettiği geniş spektrumu göz önüne aldığımızda, henüz yolun başında olduğumuzu söylememiz daha doğru olur.

Kök hücreler, farklılaşmadan kendi kendini kopyalama özelliğine sahip, bölünmeyle özelleşmiş hücre tiplerine farklılaşabilen anaç hücrelerdir. Kök hücrelerin üç önemli kaynağı, embriyonik, fetal ve erişkin dokulardır. ${ }^{[1]}$ Insanda, embriyonik dokulardaki kemik iliğinde ve yağ dokusunda bulundukları bilinmektedir. Ayrıca umbilikal kordon ve kanı, plasenta, amniyotik membranlar, amniyotik sIVı, periferik kan ve somatik dokular da diğer bilinen kaynaklardır. ${ }^{[2]}$ Kök hücreler, birkaç soya farklılaşma özelliği gösteren multipotent, birçok soya farklılaşma özelliği gösteren pluripotent ve sınırsız farklılaşma özelliği gösteren totipotent kök hücreler olarak sınıflandırılabilir. Embriyonik kök hücreler totipotent özelliğe sahip olmakla beraber, in vivo hayvan çalışmalarında tümör oluşumuna neden oldukları gösterilmiştir. ${ }^{[3]}$ Bu hücreler, teratokarsinomalar üretir ve sıklıkla kromozomal aberasyonlar kazanır. ${ }^{[3]}$ Bunun yanında, embriyoların kullanımı ve kök hücrelerin alımı sırasında zarar görmesi gibi çok ciddi etik sorunlar mevcut olup şu an için klinik kullanım yeri bulamamıştır. ${ }^{[3,4]}$ Kordon kanı hücreleri hızlı bir şekilde çoğalabilmekle beraber, temel olarak hematopoetik soy hücrelerdir ve multipotent hücre oranı \%1'in altındadır. ${ }^{[5]}$ Umbilikal kord ve plasental kök hücreler de, embriyonik ve erişkin kök hücreler arasında bir spektrumda yer alır ve tümör oluşturmadan çoğalabilir. Bunlarla ilgili de çok fazla çalışma mevcut olamamakla beraber, gelecek vaat eden bir kök hücre kaynağıdır. ${ }^{[5]}$ Kemik iliği ve yağ dokusu, erişkin kök hücrelerin klinik uygulamaları için en elverişli kaynaklardır. Sınırı nesil, nispeten düşük proliferasyon

- İletişim adresi: Dr. H. Atıl Atilla, Dışkapı Yıldırım Beyazıt Eğitim ve Araştırma Hastanesi, Ortopedi ve Travmatoloji Kliniği, Altındağ, Ankara Tel: 0312 - 5962000 e-posta: dratilatilla@hotmail.com

- Geliş tarihi: 20 Mart $2017 \quad$ Kabul tarihi: 20 Mart 2017 
oranları ve sınırlı farklılaşma potansiyellerine rağmen, embriyonik kök hücrelere göre daha az tümörojen olmaları ve etik problemlerin olmaması nedeni ile, klinik uygulamalarda sıklıkla kullanılmaktadır. ${ }^{[2]}$

Bir diğer kaynak ise amniyotik sıvı ve membran kaynaklı hücrelerdir. Bunlar, rutin olarak amniyosentezle veya doğum sonrası temin edilebilir ve kolayca kültüre edilip, çoğaltılıp, birçok pasaj sonrası bile hayatta kalabilir. Ayrıca, dondurularak saklanmaya da uygun olup, hazır allogreft olarak temin edilebilmektedir. ${ }^{[6,7]}$ Bu derlemede, amniyon ve amniyotik sıvı ile bunlardan kaynaklı kök hücrelerinin, kas iskelet sistemi kaynaklı hastalıklarda uygulanabilirliği ve mevcut klinik uygulamaları incelenmiştir.

\section{AMNIYON VE AMNIYOTIK SIVI KAYNAKLI HÜCRELER}

Amnion, ilk defa bir asır önce cilt yaralarının biyolojik olarak kapatılması için, daha sonraları da açık yaralarda ısı ve sıvı kaybını önleyecek şekilde temiz ve kapalı bir ortam yaratmak için kullanılmıştır. ${ }^{[8,9]}$ Yaklaşık 20 yıl önce, amniyotik sıvıdan miyosit differansiye edilmesi, amniyotik sıvının çeşitli hücre tedavileri için de bir kaynak olabileceği fikrini ortaya çıkarmıştır. ${ }^{[10]}$

Amniyotik sıvı (AS), amniyotik kavitede fetüsü saran, fetüsün rahatça hareket edip büyümesine olanak sağlayan, aynı zamanda da tampon ve bariyer görevi görerek fetüsü dış etken ve travmalardan koruyan bir sıvıdır; fetüs ve anne arasında vücut kimyasallarının geçişine de olanak tanır. ${ }^{[11]}$ AS temel olarak su ve elektrolitlerden oluşur. Bunun yanında, \%1-2'lik kısmını da glukoz, lipidler, proteinler, enzim ve hormonlar ve hücrelerden oluşturur. ${ }^{[11]}$ AS hücreleri, plasenta ve fetal membran gibi embriyon dışı yapılardan köken aldığı gibi, embriyo ve fetal dokulardan da kaynaklanır. AS'deki hücreler, morfolojik ve büyüme karakteristiklerine göre epitoloid $(\% 33,7)$, AS hücreleri $(\% 60,8)$ ve fibroblastik hücreler $(\% 5,5)$ 'den oluşur. ${ }^{[11]}$ AS kaynaklı kök hücreler ise temel olarak iki ana başlık altında incelenir: AS kaynaklı mezenkimal kök hücreler ve AS kök hücreleri (Tablo 1). ${ }^{[11]}$

Mezenkimal kök hücreler, mezoderm kaynaklı dokular olan adipojenik, kondrojenik, miyojenik ve osteojenik hücrelere farklılaşabilen multipotent bir hücre grubudur. Kemik iliği, adipoz dokular, iskelet kası, karaciğer ve beyin gibi erişkin dokulardan olduğu gibi, fetal ve embriyon dışı dokular olan plasenta ve amniyondan da izole edilmiştir. In't Anker ve arkadaşları, kemik iliği kökenli mezenkimal kök hücreler ile benzer fenotip ve multipotent farklılaşma potansiyeli olan hücreler tespit etmişler ve bunlara "Amniyotik Sıvı Mezenkimal Kök Hücreler" (ASMKH) adını vermişlerdir. ${ }^{[13]}$ Bu hücrelerin, in vitro ortamda fetüs ve erişkin kaynaklı mezenkimal kök hücrelerden çok daha hızlı çoğalabildikleri tespit edilmiştir. ${ }^{[14]}$

Diğer AS kaynaklı kök hücreler ise amniyotik sıvı kök hücredir (ASKH). AS'nin pluripotent kök hücreler

Tablo 1. Embriyonik kök hücreler, amniyotik membran ve ASKH'nin özelliklerinin karşılaştırılması [12]

\begin{tabular}{|c|c|c|c|c|}
\hline & $\begin{array}{l}\text { Embriyonik Kök } \\
\text { Hücre }\end{array}$ & $\begin{array}{l}\text { Amniyotik Epiteliyal } \\
\text { Hücre }\end{array}$ & $\begin{array}{l}\text { Amniyotik } \\
\text { Mezenkimal Kök } \\
\text { Hücre }\end{array}$ & $\begin{array}{l}\text { Amniyotik Sivı Kök } \\
\text { Hücre }\end{array}$ \\
\hline Kaynak & Preimplante Embriyo & Amniyotik Membran & Amniyotik Membran & Amniyotik Sivı \\
\hline $\begin{array}{l}\text { Hücre Dıșı Yaşam } \\
\text { Döngüsü }\end{array}$ & $300+$ nesil bölünme & 14 nesil Bölünme & 27 nesil bölünme & $250+$ nesil bölünme \\
\hline $\begin{array}{l}\text { Farklılaşma } \\
\text { potansiyeli }\end{array}$ & $\begin{array}{l}\text { Ektodermal } \\
\text { Mezodermal } \\
\text { Endodermal }\end{array}$ & $\begin{array}{l}\text { Ektodermal } \\
\text { Mezodermal } \\
\text { Endodermal }\end{array}$ & $\begin{array}{l}\text { Ektodermal } \\
\text { Mezodermal } \\
\text { Endodermal }\end{array}$ & $\begin{array}{l}\text { Ektodermal } \\
\text { Mezodermal } \\
\text { Endodermal }\end{array}$ \\
\hline Tümör oluşumu & Evet & Yok & Bilinmiyor & Yok \\
\hline Etik Sorun & Evet & Yok & Yok & Sinırlı* \\
\hline Klinik Çalışma & Var & Var & Yok & Yok \\
\hline
\end{tabular}

*Doğum sonrası amniyotik dokunun alınması veya amniyosentez sırasında alınan dokunun otogreft olarak kullanılmasında etik sorun bulunmamaktadır; ancak, amniyosentez ile alınan dokuların allogreft olarak kullanımında etik sorunlardan bahsedilebilir. 
içerdiği, pluripotentlik belirteci olan Oct 4'ün bulunması ile ortaya çıkarılmıştır. ${ }^{[15]} \mathrm{Bu}$ hücreler, AS'de bulunan hücrelerin $\% 0,1$ ile $0,5^{\prime} i$ arasındadır. ${ }^{[15]} \mathrm{ASKH}$, hem embryonik hem de erişkin hücre yüzey belirteçlerine sahiptir ve hızla çoğalır. ${ }^{[15]}$ Otuz altı saatte iki katına varan çıkma hızları tespit edilmiştir. Öte yandan, pluripotent olmalarına rağmen tümör oluşumuna neden olmadıkları da gösterilmiştir. ${ }^{[16]}$ Klinik olarak amniyotik kök hücre transplantasyonu yapılan, lizozomal depo hastalığı olan hasta serisinde tümör oluşumu izlenmemiştir. [17] İmmün sistemi baskılanmış farelerde dahi tümör oluşumuna neden olmadıkları, ayrıca doku kültürlerinde de genetik olarak stabil oldukları gösterilmiştir. ${ }^{[18]}$ ASKH'nin, telomer boyunu ve normal karyotipini koruyarak 250 soy ikiye katlanmasını devam ettirdiği gösterilmiştir. ${ }^{[19]}$ ASKH'nin, pluripotensite belirteçlerinin yanı sıra, mezenkimal, nöral ve epiteliyal belirteçlere de sahip olduğu gösterilmiştir (Tablo 2). ${ }^{[20]}$ Embriyonik kök hücrelerde olan etik sorunlar, imha edilecek bir dokudan greftin alınması nedeni ile, yok denilecek kadar azdır. Mevcut ticari allogreftlerin hemen tamamı, doğum sonrası imha edilecek dokuları greft olarak kullanmaktadır. Ikinci trimester'da amniyosentez ile AS'nin temininde ise, otogreft olarak kullanılması gereken bir hastalık varsa yine etik sorun olmamakta, ancak allogreft olarak kullanılacak dokunun amniyosentez ile temin edilmesi, embriyonik kök hücre teminine nispeten az da olsa etik bir sorun teşkil edebilir (Tablo 1).

\section{AMNIYOTIK MEMBRAN VE SIVI KAYNAKLI DOKU VE HÜCRE PRE-KLINIK VE KLINIK UYGULAMALARI}

Amniyotik membran ve sıvı kaynaklı allogreftler, sıkIıkla oftalmolojide kullanım alanı bulmuş olup korneal yaralanmalarda rejeneratif skafold olarak kullanılmaktadır. ${ }^{[21]}$ Yine bir diğer yaygın kullanımı ise, plastik cerrahide yanık ve yara iyileşmesine katkı sağlaması nedeniyledir. ${ }^{[22]}$ Amniyotik membran ve sıvı allogreftleri, diyabetik ayak ülserlerinde veya enfekte ve iyileşmeyen yaralarda da kendilerine klinik kullanım alanı bulmuştur. ${ }^{[23,24]}$ Gerek ASMKH gerekse ASKH ile ilgili olarak kas iskelet sistemini ilgilendiren pre-klinik çalışmalar yapılarak, bunların etkinlikleri araştırılmıştır.

Eklem kıkırdak dokusu mühendisliğinde mezenkimal kök hücrelerin kullanımı giderek artmaktadır. Adipoz doku, AS, kan, kemik iliği, dermis, embriyonik kök hücreler, infrapatellar yağ dokusu, kas, periost, plasenta, sinoviyum, trabeküler kemik ve umbilikal kord gibi çeşitli kaynaklardan elde edilebildiği gösterilen mezenkimal kök hücrelerin, kemik iliği ve umbilikal korddan elde edilenleri çeşitli klinik çalışma aşamalarındadır. ${ }^{[25]}$ Diğer kaynaklarla ilgili sıklıkla pre-klinik çalışmalar mevcuttur. In vitro ve in vivo olarak amniyotik sivı ve mezenkimal kök hücreler, karşılaştırılabilir oranlarda kondrosite differansiye olur. Gerek doğum sırasında AS'den fibroblastoid tipte hücreler olarak temin edilsin gerekse C-kit pozitif hücrelerin manyetik olarak toplanması ile elde edilen hücreler olsun, ASKH TGF $\beta 1$ ve IGF-1 ile muamele edildiğinde, artmış Tip 2 kollajen yapımı ve GAG üretimi gösterir. ${ }^{[26]}$ Kolambkar ve arkadaşları, ASKH'nin kondrojenik soya differansiye olabildiğini ve kıkırdak tamirinde kullanılabileceğini göstermişlerdir. ${ }^{[27]}$ Park ve arkadaşları, TGF- $\beta 3$ ile karıştırılmış fibrin bir hidrojel içinde, kemik iliği, yağ dokusu ve AS kaynaklı mezenkimal kök hücrelerin kondrojenik farklılaşma kapasitelerini karşılaştırdıkları çalışmalarında, in vivo ve in vitro olarak tüm kaynaklarda benzer sonuçlar bulmuşlardır. ${ }^{[28]}$ Kunusaki ve arkadaşları, AS kaynaklı mezenkimal kök hücrelerden kıkırdak greftler üreterek, bunları koyun fetüsü trakeal defektlerinin

Tablo 2. Amniyotik kök hücrelerin sahip oldukları yüzey belirteçleri

\begin{tabular}{l|l|l|l}
\hline MEZENKIMAL & NÖRAL & EPITELIYAL & PLURIPOTENSITE \\
\hline CD90 & S3-tubulin & Keratin 19 & Oct4 \\
\hline CD73 & Nestin & P63 & Nanog \\
\hline CD105 & Pax6 & & Rex-1 \\
\hline CD13 & & & \\
\hline CD29 & & & \\
\hline CD44 & & & \\
\hline CD146 & & &
\end{tabular}


tamirinde kullanmışlardır. ${ }^{[29]}$ Nadri ve arkadaşları, fare kemik iliği ve AS kaynaklı kök hücreleri karşılaştırdıkları çalışmalarında, ASKH'nin daha kolay elde edilebildiğini ve kemik iliğine kıyaslandığında adipojenik dokuya farklılaşmasının hiç olmadığını tespit etmişlerdir. ${ }^{[30]}$ AS kaynaklı kök hücrelerin kas rejenerasyonunda da etkili olduğu gösterilmiştir. Pisciotta ve arkadaşları, Duschennne musküler distrofisi olan farelerde, miyojenik olarak differansiye ettikten sonra kas içine enjekte ettikleri ASKH ve bunların parakrin etkileri ile, anjiyogenezisin tetiklenmesi, fibrozisin azalması ile distrofik kasın histopatolojisinde bir gelişme sağladıklarını tespit etmişlerdir. ${ }^{[31]}$ AS'den başarılı şekilde osteojenik hücre farklılaşması yapıldığını gösteren çeşitli protokoller bildirilmiştir. ${ }^{[32]}$ Steigman ve arkadaşları, in vitro ortamda nanofibröz skafold üzerinde osteojenik olarak differansiye edilen ASMKH'lerle, tavşan sternal defektlerinin tamirini sağlamışlardır. ${ }^{[33]}$ Sun ve arkadaşları, daha önceleri erişkin mezenkimal kök hücrelerinin osteojenik transformasyonu için kullanılan rhBMP7'ye ASKH'nin çok daha kuvvetli bir şekilde cevap verdiğini ve bu yolla osteojenik transformasyon ve doku mühendisliği yapılabildiğini göstermişlerdir. ${ }^{[34]}$ Peister ve arkadaşları, in vitro doku mühendisliğinde kemik iliği kaynaklı mezenkimal kök hücrelerin hızlı matriks oluşturması açısından üstün olduğunu, ancak uzun dönemde ASKH'nin daha sağlam bir mineralizasyon oluşturduğunu göstermişlerdir. ${ }^{[35]}$ Rodriques ve arkadaşları, hayvan deneyi çalışmalarında, ASKH'nin kaynamamış kemik defektlerinde kemik rejenerasyonunu ve anjiyogenezi arttırabileceğini

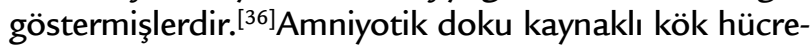
lerden kondrojenik ve osteojenik transformasyon ile olduğu kadar, tendon ve bağ transformasyonu ve rejenerasyonu ile ilgili de pre-klinik çalışmalar mevcuttur. ${ }^{[37]}$

Genel bilimsel odaklanma AS kaynaklı doku mühendisliği ve hücre tedavisi olsa da, amniyotik membran ve AS'nin, hasarlı dokuların korunması ve doku tamirinin stimüle edilmesi gibi parakrin etkileri de olabilir ve bunlar ekzojen faktörlerin salınımı için vektör görevi görebilir. ${ }^{[12]}$ AS epidermal büyüme faktörü, IGF-I, IGFII, FGF, fibronektin, laminin hiyaluronik asit, kondroitin sülfat ve hiyaluronik asit aktive edici faktör gibi bazı kemik ve kıkırdak tamir mekanizmalarında yerleri olan ekstrasellüler makromoleküller yönünden de zengindir. ${ }^{[38]}$ Özgenel ve arkadaşları, fare kulak perikondriumunda AS'nin kondrogenezi arttırdığını tespit etmişlerdir. Kavaklı ve arkadaşları, tavşan kostal kıkırdağında insan AS'sinin kondrogenezi arttırdığını tespit etmişlerdir. ${ }^{[39]}$ Öner ve arkadaşları da, yine bir hayvan deneyinde, AS'nin posterior füzyona katkı sağladığını tespit etmişlerdir. ${ }^{[40]}$ Gerek amniyotik membran ve sıvı içerisinde bulunan kök hücre etkisi gerekse bu parakrin etkiden yola çıkılarak, kas-iskelet sistemi tedavilerinde

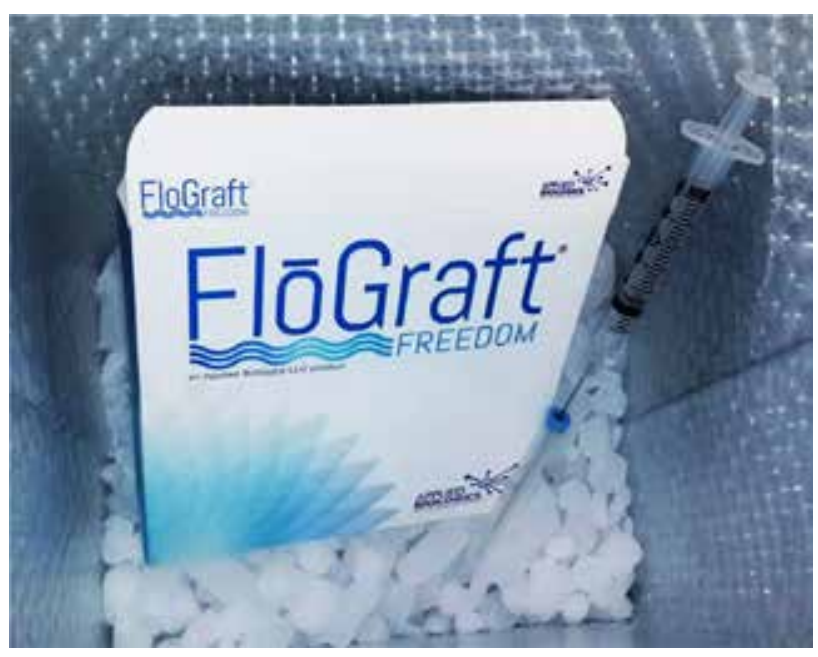

Şekil 1. Dondurulmuş AS allogrefti (karboksi buz içindeki ambalajı açıldıktan sonra eklem içi enjeksiyon için hazırlanmış 'Flograft Freedom').

çeşitli AS allogreftleri ticari olarak kullanılmaya başlanmıştır (Şekil 1).

Bu greftlerin dondurularak saklanabilmesi, canlılık oranlarını koruyabilmelerinin mümkün olması ve immünojenitesinin düşük olması, allogreft olarak ASKH ve büyüme faktörlerine ulaşımı kolay kılmaktadır (Tablo 3). ${ }^{[41]}$

AS mezenkimal kök hücreleri ve ASKH'nin kolay elde edilip hızla çoğaltılabilmesi, tümör oluşturmaması, embriyonik kök hücrelerdeki etik sorunların olmaması, düşük immünojenitesi ile allogreft olarak kullanılabilmesi, dönor saha morbiditesi yaratmaması, dondurularak saklanabilmesi gibi çeşitli özellikleri nedeni ile, rejeneratif tıpta kullanılabilecek yeni bir kaynak olabileceği değerlendirilmiş ve amniyotik doku kaynaklı allogreftlerin rejeneratif ortopedik uygulamalarda kullanımı ile ilgili çeşitli çalışmalar yapılmış olup, az sayıda klinik çalışma ile de etkinliği denenmiştir. ${ }^{[42,43]}$

\section{SONUÇ}

AS kaynaklı mezenkimal kök hücreler, erişkin mezenkimal kök hücreler gibi yüksek proliferasyon ve diferansiyasyon kapasitesine sahiptir. AS'den elde edilen bir başka kök hücre grubu olan ASKH de, embriyonik ve erişkin kök hücre arasında kalan yepyeni bir kök hücre sınıfıdır. ASKH, üç germ yaprağına da diferansiyasyon kapasitesi olan, öte yandan embriyonik kök hücreler gibi in vivo ortamda tümör oluşumuna neden olmayan yapısıyla, doku mühendisliği ve çeşitli hastalıkların kök hücre ile tedavisinde kullanılabilecek büyük bir potansiyele sahiptir. Ayrıca, 
Tablo 3. Ticari olarak temin edilebilen çeşitli amniyon ve amniyon sıvısı kaynaklı allogreftler ve kullanım alanları

\begin{tabular}{|c|c|c|c|c|c|}
\hline Firma & Ürün & Kaynak Doku ve ișlem & İçerik & Kullanım Alanı & $\begin{array}{l}\text { Üretim Yapılan Ülke ve } \\
\text { Regülasyon }\end{array}$ \\
\hline Amnio ReGen Solutions & $\begin{array}{l}\text { PalinGen }{ }^{\circledR} \text { Flow } \\
\text { PalinGen }{ }^{\circledast} \text { XPlus } \\
\text { Membrane }\end{array}$ & $\begin{array}{l}\text { İnsan Amniyotik } \\
\text { Membran ve Sıvı } \\
\text { Sezaryen }\end{array}$ & $\begin{array}{l}\text { Dondurulmuş enjekte } \\
\text { edilebilir amniyotik sıvı } \\
\text { kaynaklı allogreft }\end{array}$ & $\begin{array}{l}\text { Yaralanmış Doku } \\
\text { İyileşmesi } \\
\text { Ortopedik ve Spor } \\
\text { Hekimliği }\end{array}$ & $\begin{array}{l}\text { ABD } \\
\text { FDA ( } 21 \text { CFR 1270, } \\
1271)\end{array}$ \\
\hline \multirow[t]{3}{*}{ AMNIOX ${ }^{\circledast}$ Medical } & NEOX ${ }^{\otimes}$ & $\begin{array}{l}\text { İnsan Amniyotik } \\
\text { Membran ve veya } \\
\text { Umbilikal Kordon } \\
\text { Sezaryen }\end{array}$ & $\begin{array}{l}\text { Dondurulmuş İnsan } \\
\text { Amniyotik Membranı }\end{array}$ & $\begin{array}{l}\text { Küçük ve yüzeyel } \\
\text { dermal yaralanma, } \\
\text { Oftalmolojik } \\
\text { uygulamalar }\end{array}$ & $\begin{array}{l}\text { ABD } \\
\text { FDA (21 CFR 1270, } \\
1271)\end{array}$ \\
\hline & CLARIX ${ }^{\otimes} 100$ & $\begin{array}{l}\text { Insan Amniyotik } \\
\text { Membran ve veya } \\
\text { Umbilikal Kordon } \\
\text { Sezaryen }\end{array}$ & $\begin{array}{l}\text { Dondurulmuş İnsan } \\
\text { Amniyotik Membran } \\
\text { kaynaklı rejeneratif } \\
\text { Matriks }\end{array}$ & $\begin{array}{l}\text { Yanık ve Skar dokusu } \\
\text { önleme }\end{array}$ & $\begin{array}{l}\text { ABD } \\
\text { FDA ( } 21 \text { CFR 1270, } \\
1271)\end{array}$ \\
\hline & NEOX FLO VE CLARIX FLO ${ }^{\circledR}$ & $\begin{array}{l}\text { İnsan Amniyotik } \\
\text { Membran ve veya } \\
\text { Umbilikal Kordon } \\
\text { Sezaryen }\end{array}$ & $\begin{array}{l}\text { Dondurulmuş Enjekte } \\
\text { edilebilir Amniyotik sıvı } \\
\text { kaynaklı Allogreft }\end{array}$ & $\begin{array}{l}\text { Yaralanmış Doku } \\
\text { İyileşmesi } \\
\text { Ortopedik ve Spor } \\
\text { Hekimliği dahil }\end{array}$ & $\begin{array}{l}\text { ABD } \\
\text { FDA (21 CFR 1270, } \\
1271)\end{array}$ \\
\hline \multirow[t]{2}{*}{ APPLIED BIOLOGICS ${ }^{\mathrm{TM}}$} & FLŌGRAFT ${ }^{\circledR}$ & $\begin{array}{l}\text { İnsan Amniyotik SIVI } \\
\text { Sezaryen }\end{array}$ & $\begin{array}{l}\text { Dondurulmuş Enjekte } \\
\text { edilebilir Amniyotik sıvı } \\
\text { kaynaklı Alllogreft }\end{array}$ & $\begin{array}{l}\text { Ortopedik Yaralanmalar } \\
\text { Spor Hekimliği } \\
\text { Genel Cerrahi }\end{array}$ & $\begin{array}{l}\text { ABD } \\
\text { FDA-CBER Regülasyonu }\end{array}$ \\
\hline & $\begin{array}{l}\text { XWRAP }{ }^{\otimes} \text { - AMNIOTIC } \\
\text { MEMBRANE-DERIVED } \\
\text { ALLOGRAFT }\end{array}$ & $\begin{array}{l}\text { İnsan Amniyotik } \\
\text { Membran } \\
\text { Sezaryen }\end{array}$ & $\begin{array}{l}\text { Amniyotik membran } \\
\text { kaynaklı emilebilir yara } \\
\text { örtüsü }\end{array}$ & Yara yeri Onarımı & $\begin{array}{l}\text { ABD } \\
\text { FDA-CBER Regülasyonu }\end{array}$ \\
\hline ASG LLC & $\begin{array}{l}\text { ASGFluid }^{\mathrm{TM}} \\
\text { AmnioFLEX }^{\mathrm{TM}} \\
\text { ASGBarrier }^{\mathrm{TM}}\end{array}$ & $\begin{array}{l}\text { İnsan Amniyotik } \\
\text { Membran } \\
\text { Sezaryen }\end{array}$ & $\begin{array}{l}\text { Dondurulmuş enjekte } \\
\text { edilebilir Amniyotik sıvı } \\
\text { kaynaklı Alllogreft }\end{array}$ & Yara bakımı & $\begin{array}{l}\text { ABD } \\
\text { FDA (21 CFR 1270, } \\
1271)\end{array}$ \\
\hline \multirow[t]{2}{*}{ DERMA SCIENCES ${ }^{\circledR}$} & AMNIOEXCEL ${ }^{\otimes}$ & $\begin{array}{l}\text { İnsan Amniyotik } \\
\text { Membran ve Sıvı } \\
\text { Sezaryen }\end{array}$ & $\begin{array}{l}\text { Kurutulmuş İnsan } \\
\text { amniyon kaynaklı } \\
\text { Allogreft }\end{array}$ & Yara bakımı & $\begin{array}{l}\text { ABD } \\
\text { FDA (21 CFR 1270, } \\
1271)\end{array}$ \\
\hline & AMNIOMATRIX® & & $\begin{array}{l}\text { Dondurulmuş enjekte } \\
\text { edilebilir amniyotik sıvı } \\
\text { kaynaklı alllogreft }\end{array}$ & Derin Yara bakımı & $\begin{array}{l}\text { ABD } \\
\text { FDA (21 CFR 1270, } \\
1271)\end{array}$ \\
\hline In2Bones USA, LLC. ${ }^{\circledR}$ & AlloAid ${ }^{\circledR}$ & $\begin{array}{l}\text { İnsan Amniyotik } \\
\text { Membran ve Sıvı } \\
\text { Sezaryen }\end{array}$ & $\begin{array}{l}\text { Dondurulmuş enjekte } \\
\text { edilebilir Amniyotik sıvı } \\
\text { kaynaklı Alllogreft }\end{array}$ & Yara yeri onarımı & $\begin{array}{l}\text { ABD } \\
\text { FDA ( } 21 \text { CFR 1270, } \\
1271)\end{array}$ \\
\hline MiMedx ${ }^{\circledR}$ & OrthoFlo ${ }^{\otimes}$ & $\begin{array}{l}\text { İnsan Amniyotik Sıvı } \\
\text { Sezaryen }\end{array}$ & $\begin{array}{l}\text { Liyofilize Amniyotik SIVı } \\
\text { allogrefti }\end{array}$ & Eklem içi Enjeksiyon & $\begin{array}{l}\text { ABD } \\
\text { FDA (21 CFR 1270, } \\
1271)\end{array}$ \\
\hline SURGILOGIX® & $\begin{array}{l}\text { AmnioFLEX } \\
\text { SXFluid }^{T M} \\
\text { SXMatrix }^{T M} \\
\text { SXBarrier }\end{array}$ & $\begin{array}{l}\text { İnsan Amniyotik } \\
\text { Membran ve Sıvı } \\
\text { Sezaryen }\end{array}$ & $\begin{array}{l}\text { Dondurulmuş topikal } \\
\text { uygulanabilir veya } \\
\text { Enjekte edilebilir } \\
\text { Amniyotik sıvı kaynaklı } \\
\text { Canlı Hücre içeren, } \\
\text { Koriyon içermeyen, } \\
\text { Allogreft }\end{array}$ & $\begin{array}{l}\text { Spor Hekimliği, } \\
\text { Omurga ve Podiatri, } \\
\text { Jinekoloji, Üroloji } \\
\text { ve Genel Cerrahi } \\
\text { uygulamaları, } \\
\text { Yara ve hasarlı doku } \\
\text { onarımı }\end{array}$ & $\begin{array}{l}\text { ABD } \\
\text { FDA (21 CFR 1270, } \\
1271)\end{array}$ \\
\hline Vivex & AlloGen $^{\mathrm{TM}}$ & $\begin{array}{l}\text { İnsan Amniyotik SIvı } \\
\text { Sezaryen }\end{array}$ & $\begin{array}{l}\text { Dondurulmuş } \\
\text { Amniyotik Sıvı allogrefti }\end{array}$ & $\begin{array}{l}\text { Spor Hekimliği, Faset } \\
\text { Eklem İnflamasyonu, } \\
\text { Kronik Nörit, } \\
\text { Doku onarımın } \\
\text { güçlendirilmesi }\end{array}$ & $\begin{array}{l}\text { ABD } \\
\text { FDA (21 CFR 1270, } \\
1271)\end{array}$ \\
\hline
\end{tabular}

ASKH'nin immünojenitesinin çok düşük olması nedeni ile, allojenik olarak kullanımının kolay olması, amniyosentez veya doğum gibi işlem sonrası kullanılmayan bir dokunun dönor saha morbiditesi yaratmadan allogreft olarak kullanılabilecek olması da, bu sahada heyecan veren bir başka gelişmedir. Artan pre-klinik ve klinik çalışmalarla beraber, bu kök hücre ve büyüme faktörü kaynağının etkinlik ve güvenlik sahası daha iyi anlaşılacak ve klinik kullanım alanı ve sınırları netleşecektir.

\section{KAYNAKLAR}

1. Gholizadeh-Ghaleh Aziz S, Pashaei-AsI F, Fardyazar Z, Pashaiasl M. Isolation, Characterization, Cryopreservation of Human Amniotic Stem Cells and Differentiation to Osteogenic and Adipogenic Cells. PLoS One 2016;11(7):e0158281. Crossref

2. Dziadosz M, Basch RS, Young BK. Human amniotic fluid: a source of stem cells for possible therapeutic use. Am J Obstet Gynecol 2016;214(3):321-7. Crossref

3. Cowan CA, Klimanskaya I, McMahon J, Atienza J, Witmyer J, Zucker JP, Wang S, Morton CC, McMahon AP, Powers D, Melton DA. Derivation of embryonic stem-cell lines from human blastocysts. N Engl J Med 2004;350(13):1353-6. Crossref 
4. Evans MJ, Kaufman MH. Establishment in culture of pluripotential cells from mouse embryos. Nature 1981;292(5819):154-6.

5. Sun JM, Kurtzberg J. Cord blood for brain injury. Cytotherapy 2015;17(6):775-85. Crossref

6. Da Sacco S, De Filippo RE, Perin L. Amniotic fluid as a source of pluripotent and multipotent stem cells for organ regeneration. Curr Opin Organ Transplant 2011;16(1):1015. Crossref

7. Da Sacco S, Sedrakyan S, Boldrin F, Giuliani S, Parnigotto P, Habibian R, Warburton D, De Filippo RE, Perin L. Human amniotic fluid as a potential new source of organ specific precursor cells for future regenerative medicine applications. J Urol 2010;183(3):1193-200. Crossref

8. Davis, JS. Skin transplantation with a review of 550 cases at the Johns Hopkins Hospital. JHH Report 1910;15:307.

9. Gruss JS, Jirsch DW. Human amniotic membrane: a versatile wound dressing. Can Med Assoc J 1978;118(10):1237-46.

10. Streubel B, Martucci-Ivessa G, Fleck T, Bittner RE. In vitro transformation of amniotic cells to muscle cells--background and outlook. Wien Med Wochenschr 1996;146(9-10):216-7.

11. Cananzi M, Atala A, de Coppi P. Stem Cells Derived from Amniotic Fluid. In: Lanza R, Atala A, editors. Essentials of Stem Cell Biology, 3rd ed. USA: Academic Press, Elsevier Inc.; 2014. p.141-56.

12. Rennie K, Gruslin A, Hengstschläger M, Pei D, Cai J, Nikaido T, Bani-Yaghoub M. Applications of amniotic membrane and fluid in stem cell biology and regenerative medicine. Stem Cells Int 2012;2012:721538. Crossref

13. In't Anker PS, Scherjon SA, Kleijburg-van der Keur C, de Groot-Swings GM, Claas FH, Fibbe WE, Kanhai HH. Isolation of mesenchymal stem cells of fetal or maternal origin from human placenta. Stem Cells 2004;22(7):1338-45. Crossref

14. Kaviani A, Perry TE, Dzakovic A, Jennings RW, Ziegler MM, Fauza DO. The amniotic fluid as a source of cells for fetal tissue engineering. J Pediatr Surg 2001;36(11):1662-5.

15. Prusa AR, Marton E, Rosner M, Bernaschek G, Hengstschläger M. Oct-4-expressing cells in human amniotic fluid: a new source for stem cell research? Hum Reprod 2003;18(7):1489-93.

16. De Coppi P, Bartsch G Jr, Siddiqui MM, Xu T, Santos CC, Perin L, Mostoslavsky G, Serre AC, Snyder EY, Yoo JJ, Furth $\mathrm{ME}$, Soker S, Atala A. Isolation of amniotic stem cell lines with potential for therapy. Nat Biotechnol 2007;25(1):1006. Crossref

17. Miki T. Amnion-derived stem cells: in quest of clinical applications. Stem Cell Res Ther 2011;2(3):25. Crossref

18. Miki T, Strom SC. Amnion-derived pluripotent/multipotent stem cells. Stem Cell Rev 2006;2(2):133-42. Crossref

19. Joo S, Ko IK, Atala A, Yoo JJ, Lee SJ. Amniotic fluid-derived stem cells in regenerative medicine research. Arch Pharm Res 2012;35(2):271-80. Crossref

20. Davydova DA, Vorotelyak EA, Smirnova YA, Zinovieva RD, Romanov YA, Kabaeva NV, Terskikh W, Vasiliev AV. Cell phenotypes in human amniotic fluid. Acta Naturae 2009;1(2):98-103.

21. Gheorghe A, Pop M, Burcea M, Serban M. New clinical application of amniotic membrane transplant for ocular surface disease. J Med Life 2016;9(2):177-9.

22. Fairbairn NG, Randolph MA, Redmond RW. The clinical applications of human amnion in plastic surgery. J Plast Reconstr Aesthet Surg 2014;67(5):662-75. Crossref
23. Swan J. Use of Cryopreserved, Particulate Human Amniotic Membrane and Umbilical Cord (AM/UC) Tissue: A Case Series Study for Application in the Healing of Chronic Wounds. Surg Technol Int 2014;25:73-8.

24. Werber B, Martin E. A prospective study of 20 foot and ankle wounds treated with cryopreserved amniotic membrane and fluid allograft. J Foot Ankle Surg 2013;52(5):615-21. Crossref

25. Ahmed TA, Hincke MT. Mesenchymal stem cell-based tissue engineering strategies for repair of articular cartilage. Histol Histopathol 2014;29(6):669-89. Crossref

26. Preitschopf A, Zwickl H, Li K, Lubec G, Joo G, Rosner M, Hengstschläger M, Mikula M. Chondrogenic differentiation of amniotic fluid stem cells and their potential for regenerative therapy. Stem Cell Rev 2012;8(4):1267-74. Crossref

27. Kolambkar YM, Peister A, Soker S, Atala A, Guldberg RE. Chondrogenic differentiation of amniotic fluid-derived stem cells. J Mol Histol 2007;38(5):405-13. Crossref

28. Park JS, Shim MS, Shim SH, Yang HN, Jeon SY, Woo DG, Lee DR, Yoon TK, Park KH. Chondrogenic potential of stem cells derived from amniotic fluid, adipose tissue, or bone marrow encapsulated in fibrin gels containing TGF- $\beta 3$. Biomaterials 2011;32(32):8139-49. Crossref

29. Kunisaki, SM, Freedman, DA, Fauza DO. Fetal tracheal reconstruction with cartilaginous grafts engineered from mesenchymal amniocytes. J Pediatr Surg 2006;41:675-82. Crossref

30. Nadri S, Soleimani M. Comparative analysis of mesenchymal stromal cells from murine bone marrow and amniotic fluid. Cytotherapy 2007;9(8):729-37. Crossref

31. Pisciotta A, Riccio M, Carnevale G, Lu A, De Biasi S, Gibellini L, La Sala GB, Bruzzesi G, Ferrari A, Huard J, De Pol A. Stem cells isolated from human dental pulp and amniotic fluid improve skeletal muscle histopathology in $\mathrm{mdx} / \mathrm{SCID}$ mice. Stem Cell Res Ther 2015;6:156. Crossref

32. Pipino C, Pandolfi A. Osteogenic differentiation of amniotic fluid mesenchymal stromal cells and their bone regeneration potential. World J Stem Cells 2015;7(4):681-90. Crossref

33. Steigman SA, Ahmed A, Shanti RM, Tuan RS, Valim C, Fauza $D O$. Sternal repair with bone grafts engineered from amniotic mesenchymal stem cells. J Pediatr Surg 2009;44(6):1120-6. Crossref

34. Sun H, Feng K, Hu J, Soker S, Atala A, Ma PX. Osteogenic differentiation of human amniotic fluid-derived stem cells induced by bone morphogenetic protein-7 and enhanced by nanofibrous scaffolds. Biomaterials 2010;31(6):1133-9. Crossref

35. Peister A, Woodruff MA, Prince JJ, Gray DP, Hutmacher DW, Guldberg RE. Cell sourcing for bone tissue engineering: amniotic fluid stem cells have a delayed, robust differentiation compared to mesenchymal stem cells. Stem Cell Res 2011;7(1):17-27. Crossref

36. Rodrigues MT, Lee BK, Lee SJ, Gomes ME, Reis RL, Atala A, Yoo JJ. The effect of differentiation stage of amniotic fluid stem cells on bone regeneration. Biomaterials 2012;33(26):606978. Crossref

37. Riboh JC, Saltzman BM, Yanke AB, Cole BJ. Human Amniotic Membrane-Derived Products in Sports Medicine: Basic Science, Early Results, and Potential Clinical Applications. Am J Sports Med 2016;44(9):2425-34. Crossref

38. Ozgenel GY, Filiz G, Ozcan M. Effects of human amniotic fluid on cartilage regeneration from free perichondrial grafts in rabbits. Br J Plast Surg 2004;57(5):423-8. Crossref 
39. Kavakli K, GurkokS, Caylak H, Genc O, Gamsizkan M, Yucel O, Karasahin E, Gozubuyuk A, Tasci C. Effects of human amniotic fluid on costal cartilage regeneration (an experimental study). Thorac Cardiovasc Surg 2011;59(8):484-9. Crossref

40. Oner M, Dulgeroglu TC, Karaman I, Guney A, Kafadar IH, Erdem S. The effects of human amniotic fluid and different bone grafts on vertebral fusion in an experimental rat model. Curr Ther Res Clin Exp 2015;77:35-9. Crossref

41. Janz Fde L, Debes Ade A, Cavaglieri Rde C, Duarte SA, Romão CM, Morón AF, Zugaib M, Bydlowski SP. Evaluation of distinct freezing methods and cryoprotectants for human amniotic fluid stem cells cryopreservation. J Biomed Biotechnol 2012;2012:649353. Crossref
42. Hanselman AE, Tidwell JE, Santrock RD. Cryopreserved human amniotic membrane injection for plantar fasciitis: a randomized, controlled, double-blind pilot study. Foot Ankle Int 2015;36(2):151-8. Crossref

43. Zelen CM, Poka A, Andrews J. Prospective, randomized, blinded, comparative study of injectable micronized dehydrated amniotic/chorionic membrane allograft for plantar fasciitis -a feasibility study. Foot Ankle Int 2013;34(10):1332-9. Crossref 